DOI 10.14746/ssp.2019.2.3

\author{
Mira MalczyŃSKA-Bialy \\ University of Rzeszów \\ ORCID: 0000-0003-3083-800X
}

\title{
Education and information in consumer policy in the Republic of Poland
}

\begin{abstract}
The article is based on an analysis of national and European legal acts, documents and source literature and its aim is to describe education and information in consumer policy in Poland. The protection of consumer rights within the scope of information and education is presented as a prime objective of the consumer policy strategy of the European Union and government programs of consumer policy in Poland. Certain aspects of information and education policy of the government are investigated, which are included in the Consumer Policy Strategy 2014-2018. The competencies of consumer authorities in the institutional context are thoroughly discussed in terms of education and information in Poland. Moreover, the consumer identity of information and education policy between Poland and the European Union is indicated.
\end{abstract}

Key words: consumer, consumer rights, consumer policy, Office of Competition and Consumer Protection, Trade Inspection, Association of Polish Consumers, Polish Consumer Federation

\section{Introduction}

The need for consumer protection in the area of information and 1 education results from the disparity between professionals and consumers. The adequate knowledge of purchasers of the terms and conditions of contracts, the safety of products, unfair market practices and ways of pursuing claims are essential for their full participation in market mechanisms.

While economic entities demonstrate a vast knowledge of consumer policy, consumer expertise is rather superficial and limited. The principal objective of the article is to present the inclusion of education and information in consumer policy in Poland. In order to do that, the identity of the European Union policy was analyzed together with the national consumer policy. Furthermore, the main goals of contemporary consumer 
policy in Poland are examined within the context of consumer information and education.

The subject of this article is the consideration of education and information in consumer policy in the Republic of Poland after 1998. It focuses on the measures of particular authorities, such as the Office of Competition and Consumer Protection (UOKiK) and consumer entities, for example, the Polish Consumer Federation and Polish Consumer Association.

The chronological study area covered the period after 1998. The government's implementation of the first consumer policy program for the years 1998-1999 forms an initial period of study. In 2014, basic assumptions of the seventh consecutive policy paper for the years 2014-2018 were highlighted. It summarized the action taken by the Republic of Poland towards improving the level of consumer rights protection in the Polish market, as well as providing equal opportunities in a community market.

The following research questions were asked: what initiatives should be undertaken to enhance information and education measures in consumer policy? What are the barriers in consumer education? How important are consumer education and information in government consumer policy programs? To what extent does the Republic of Poland meet EU standards in terms of education and information activities?

The article is based on the following assumptions: consumer education and information were indicated as a prime goal in every government consumer policy program, which varied according to the measures taken in order to complete it. What is more, contemporary EU consumer policy defines minimum standards which a member state needs to achieve.

The basic research method employed in this paper is content analysis. It was used to investigate European and national legal acts and government consumer policy programs. In the article, a comparative analysis is also performed to compare the information and education consumer policy carried out by the state after 1998. Furthermore, the elements of a system analysis are implemented, since consumer policy is perceived as a subsystem of European community policies. Finally, some elements of a decision-making method are used to analyze the process of implementing the political decisions of the President of the Council of Ministers. The decisions concern the adoption of consumer policy strategies by means of appropriate informational and educational measures, as well as legal action. 
The exegesis of the chosen aspects of EU and national legal acts within the scope of consumer protection and consumer policy were of key importance while analyzing education and information in consumer policy in the Republic of Poland. The texts of government strategies and consumer policy programs were examined, which had been developed by the Office of Competition and Consumer Protection and adopted by the President of the Council of Ministers in the years 1998-2004, emphasizing the demands and activities connected with education and information. Additionally, consumer policy entities in Poland, which influence purchasers' information and education, were characterized. A wide array of methods specific to political studies was used, namely; legal and institutional analysis, and historical and systems analysis.

When investigating consumer education and information in consumer policy, two spheres could be indicated at the national level. The first one is connected with the process of increasing consumer knowledge through education (schools, educational campaigns organized by governmental authorities, consumer organizations, media activity). The second one, on the other hand, is linked to providing a suitable legal environment by vendors and entrepreneurs, as well as supplying relevant and law-abiding information (on packages, labels, and prices shown in advertisements). Article 546 of the Civil Code in Polish law requires sellers to provide buyers with explanations regarding the legal and actual relations concerning the product sold and providing necessary documentation, such as manuals (Ustawa z dnia 23 kwietnia 1964 r. - Kodeks). Lack of instruction manuals curtails the freedom of general assessment and free market choice for consumers. The foundation of a right choice is based on factual information about the characteristics of products and services offered, the conditions of safe usage of products and complaints procedures (Dutkiewicz, 1998, pp. 280-285). According to the rules in civil law, the information concerning products and services ought to be substantive, reliable and complete. It works on the principle that "a well-informed consumer becomes a well-protected consumer” (Łętowska, 2004, p. 123).

\section{Education and information in consumer policy programs in Poland}

Developing consumer knowledge is one of the priorities of Polish government policy in the context of consumer education and information. Consumer policy consists of a vast number of the country's conscious ac- 
tions leading to the creation of such conditions that enable consumers to achieve their goals and fulfill their expectations (Niepokulczycka, 1993, p. 12). Education and information play a key role in domestic and international consumer policy, as evidenced by the inclusion of broadly-understood education in basic consumer policy instruments ${ }^{1}$ by the Organization for Economic Cooperation and Development (OECD) (Consumer, 2010 , p. 77). The appropriate knowledge and awareness of consumers constitute the basis for the implementation of particular programs and demands of consumer protection included in government strategies. In 1998, the government started to pay more attention to consumer protection in education and information by launching, for the first time in the history of Poland, a consumer program entitled Government Project of Consumer Policy 1998-1999, and later a number of subsequent documents, such as Government Consumer Policy Program 1998-1999, Government Consumer Policy 2000-2001, Government Consumer Policy 2002-2003, Strategy of Consumer Policy 2004-2006, Strategy of Consumer Policy 2007-2009 and Strategy of Consumer Policy 2010-2013. In practice, it entailed the need for education and the provision of relevant consumer information at every step of the transaction process. Consumer Policy 2014-2018 is the currently applicable program (Polityka, 2014.).

One of the main priorities included in the program for the years 2014-2018 is "raising consumer awareness - the policy of education and information." Within that framework, the President of the Office of Competition and Consumer Protection has planned informational and educational actions and projects, the purpose of which is to spread legal and economic knowledge among all market participants, in particular children and teenagers, as well as consumers over the age of sixty. These educational actions were intended to trigger an increase of awareness of consumer rights, to enable consumers to seek redress more effectively and adopt a critical attitude towards certain market offers.

The campaigns for children and teenagers aim to develop their consumer consciousness at an early stage of education. Youths, actively participating in purchase decision-making, have a positive influence on the purchasing decisions of adult family members. The initiatives for adults aim at the intellectual support of those particularly vulnerable to unfair market practices used by sellers. Elements of consumer knowledge are

1 The other instruments are contract terms, standards of behaviors and good market practices, permits from companies and service providers, financial instruments, the ways of pursuing claims and redress mechanisms. 
provided by universities of the third age and senior citizens clubs. The Office of Competition and Consumer Protection also undertakes educational initiatives for entrepreneurs. The main idea of these actions is to adopt a pro-consumer attitude, in particular assent to reaching an amicable settlement of disputes with consumers, such as mediation, arbitration and courts of conciliation, as an alternative to judicial redress.

The informative measures taken in the years 2014-2018 are closely connected with the legislative process as well as current judicial decisions of the President of the Office of Competition and Consumer Protection. They inform about current proceedings and decisions of the President and provide information concerning market research. Furthermore, various educational activities are also undertaken in relation to current or new consumer laws. This requires conducting an intensive campaign targeted at all market participants. Additionally, clear and coherent information and educational measures targeted at particular consumer groups is of key importance, taking account of their age, education and place of residence.

In line with the consumer policy of information and education in the years 2014-2018, close cooperation with the media has also been developed. Conferences, debates, workshops and seminars have been held for a wide target audience and have created opportunities for experts, consumers, entrepreneurs and administrative employees to exchange opinions. The findings of social research, conclusions, recommendations as well as information campaigns are all made available on the website of the Office of Competition and Consumer Protection in order to reach the widest possible group of people. Highly specialized authorities and institutions have been involved in carrying out information and education activities in the years 2014-2018. For instance, the Polish Financial Supervision Authority, in the period of the binding document, has been responsible for organizing seminars for representatives of institutions involved in consumer protection and academics.

In the telecommunication services sector, the Office of Electronic Communication introduced a system of certification for telecommunication services; for example, certificates in the Safer Internet category, which facilitates consumer activity on the telecommunication services market. The Ministry of National Education continues these educational measures by spreading knowledge about consumer rights. Furthermore, the National Centre for Supporting Vocational and Continuing Education has devised an exemplary curriculum, which includes such elements as consumer rights and complaints procedures. 
The postulate regarding spreading legal and economic consumer knowledge among children and teenagers, included in government programs on consumer policy in Poland, is connected with the introduction of elements of consumer knowledge into the core curriculum in schools. This is defined as an obligatory set of educational aims and contents, described in the form of general and specific requirements regarding the knowledge and skills needed by a student after completing a particular stage of education (Ustawa z dnia 7 września 1991 r. o systemie). On the basis of the Regulation of the Minister of National Education of February 14, 2017 on the core curriculum for pre-school education and the core curriculum for general education in primary schools, we can observe that consumer education does not play a significant role in the teaching content in those age groups. The ability to use ICT technologies, in particular searching and making use of information, is one of the educational aims included in the regulation for I-III grades. This skill might be useful in purchasing processes.

In grades V-VIII the teaching content of particular subjects, such as Biology, includes elements of consumer knowledge, specifically elements of ecology and environmental protection.

Consumer education also involves students in primary schools with moderate to severe intellectual disabilities acquiring knowledge about purchasing processes within the core curriculum for general education. Learning about new types of shops, planning and doing the shopping, as well as recognizing the expiry dates of products are crucial examples here.

Elements of consumer policy were also included in the core curriculum for primary schools within the subject of business studies. The teaching content for this subject involves, among other things, ways of seeking redress. The student gains knowledge about some aspects of consumer rights and their institutions, the rules for making complaints where a product is unfit for purpose, being able to distinguish between information and persuasion in an advertisement, and, finally, to indicate the benefits and drawbacks of advertisements and their influence on consumers. The issues of household income and expenditure, investing money and consumer protection are also taken into account. It is essential to develop a critical approach towards the interpretation of the information in ads and to show both positive and negative instances of their effects on consumers. Consumer knowledge at a higher educational level depends on the type of school and education profile (high school, technical colle- 
ge, vocational school, post-secondary school) (Rozporządzenie Ministra Edukacji Narodowej z dnia 14 lutego 2017 r. w sprawie).

\section{The entities in charge of consumer information and education in Poland}

Consumer information and education in Poland are supervised by the President of the Office of Competition and Consumer Protection (Ustawa z dnia 16 lutego 2007 roku o ochronie), the Office of Competition and Consumer Protection (Rozporządzenie Prezesa Rady Ministrów z dnia 5 lutego 1997 roku $w$ sprawie), the Trade Inspection (Ustawa $\mathrm{z}$ dnia 15 grudnia 2000 r. o Inspekcji) and local government units (Ustawa z dnia 24 lipca 1998 r. o zmianie) as well as consumer organizations (Ustawa z dnia 7 kwietnia 1989 r. - Prawo). The President of the Office of Competition and Consumer Protection is the head of the government administration responsible for the protection of competition and consumers. Under Article 31, section 12 of the Act of 16 February 2007 on competition and consumer protection, the President arranges publication and education programs disseminating knowledge of consumer rights. The President is also obliged to gather and publicize judicial decisions on consumer protection, in particular by publishing important decisions on the website of the Office of Competition and Consumer Protection (Article 31, section 15). The President performs his tasks with the help of the Office (Article 28 , section 6 , of 20 June 2007 on competition and consumer protection). The Consumer Protection Department is in charge of the promotion of information and educational activities of the Office. Its central role is to create and develop government consumer policy in that area. Furthermore, it supports local government units and community organizations as well as initiates product and service analyses in terms of education and information (Departamenty). The main responsibilities of the Office of Competition and Consumer Protection and Trade Inspection are to exercise control over usage of the Polish language in the performance of public tasks and legal transactions within the territory of the Republic of Poland (Ustawa z dnia 7 października 1999 r. o języku). Both institutions ensure foreign terms are not used exclusively in Polish legal transactions, and that foreign products and service descriptions, as well as offers and advertisements have a Polish language version (10 lat, 2000, p. 15). The Trade Inspection's authorities cooperate with district consumer advocates 
and non-governmental organizations, which represent consumer interests, in order to share knowledge and exchange information about market practices which violate consumer rights (Obwieszczenie Prezesa Rady Ministrów z dnia 19 maja 2018 r. w sprawie). Since 1999, the Trade Inspection has published a quarterly entitled Biuletyn Inspekcji Handlowej to perform government consumer policy tasks in education and information.

Consumer education on consumer protection is also the responsibility of local authorities under Article 38 of the Act on competition and consumer protection. The introduction of elements of consumer knowledge into the school curriculum is of key importance (Ustawa z dnia 7 września 1991 r. o systemie). The district consumer advocate performs tasks connected with information and education related to consumer protection (Article 38 section 1 of the Act on Competition and Consumer Protection). The type of information given ranges from minor issues linked with advertisements of everyday products to serious problems with credit agreements. In many cases, the main role of a consumer advocate is to familiarize consumers with their rights and help them take the right direction (Kirstein, 2006, p. 199). Additionally, there are also various consumer organizations that contribute to public access to consumer information and education. The Polish Consumer Federation and Polish Consumer Association are nationwide organizations responsible for consumer protection. The Polish Consumer Federation is a voluntary, self-governing consumer organization. One of the main aims of the Federation is the creation of a system of individual consumer interests' protection in order to guarantee access to reliable information about products and services, as well as consumer education. The Consumer Federation informs consumers about the advantages of available products and those recently launched on the market, and warns consumers against purchasing goods and services of poor quality (Statut Federacji). The Federation is highly active regarding consumer information and education, thereby creating the opportunity for consumers to make conscious, rational and safe choices. Their purpose is to make consumers aware of the pitfalls linked to consuming products with harmful substances, to carry out research on the assessment of the level of consumer awareness of the quality of groceries and the content of consumer education in general education. Additionally, they aim to study the influence of consumers on the quality of the Polish market economy, informing consumers about their rights, and the dangers associated with the use of certain products, and providing the public with the results of product assessments through press releases, and TV and radio broadcasts 
(Niepokulczycki, Zborowska, 1993, pp. 32-33). The main function of the Consumer Federation is to offer consumers a free counselling service and help in case of redress. It also performs its tasks in the area of drawing up and publicizing educational programs, testing products and services and publishing its results, and finally, publishing magazines, research reports, brochures and leaflets (Wymysłowski, 2006, pp. 244-245).

The Polish Consumer Association is responsible for raising consumer awareness with regard to their right to information and education. The function in question is performed in association with non-governmental organizations. Since 2001, The Polish Consumer Association, on behalf of the Office of Competition and Consumer Protection, has offered a legal consultation desk for consumer rights adviser and published a quarterly entitled Bulletin informing about judicial decisions concerning consumer rights. The Association also carries out a number of tasks intended for young consumers (Rokicka, 2003, p. 12); for instance, educational projects, a guide to consumer rights in Poland and the EU, and various competitions for students connected with food safety and marketing tricks (Łuczak, 2006, p. 192.)

\section{On Polish consumer policy in education and information and EU standards}

Treaties, directives and resolutions constitute the basis for consumer policy in terms of education and information in the European Union. Consumer protection, as an element of EU policy, was clearly set out in the Treaty of Maastricht. Under Article 129a (1) of the Treaty, the EU was supposed to trigger the attainment of a high level of consumer protection in the field of health and safety, the economic interests of consumers and providing them with information (Treaty on European Union). Under Article 153 of the Treaty of Amsterdam, consumer rights were extended by the consumers' right to information and education, and their right to organize themselves in order to safeguard their interests (The Treaty of Amsterdam).

The process of amending Polish legislation to meet EU standards regarding consumer protection started in 1991 with the signing of the Association Agreement, which entered into force on February 1, 1994 (Układ Europejski).

Consumer protection in terms of education and information can be analyzed on two different planes. The first is the education of the Euro- 
pean consumer, and increasing their awareness in the economic and legal context, which enables them to participate efficiently and consciously in a free market economy. It is also worth mentioning the Resolution on consumer education in primary and secondary schools (Resolution of the Council). The consumer right to information ought to guarantee a free, self-determining choice and safety. Consequently, it brought about interventions in the content and form of information provided in particular situations.

The second one is connected with the provision of reliable information by entrepreneurs and vendors about products available on the market. There are two types of information expected by consumers, namely product information and information about the terms and conditions of consumer contracts. As for the former, each product should be labelled with essential information, such as its characteristics, purpose and instructions for use.

The EU directives paid special attention to the mass purchasing of products, for example food, cosmetics, medicines and toys for children. Precise information about their components, use and possible dangers was of key importance. Therefore, EU legislation imposed a large number of strict obligations concerning labelling, both regulating giving information correctly and banning certain contents within labels (Streżyńska, 2000, p. 98). A good example is the Council Directive 79/112/EEC of 18 December 1978 on the approximation of the laws of the Member States relating to the labelling, presentation and advertising of foodstuffs for sale to the ultimate consumer (Council Directive 79/112/EEC). Under Article 2 of the directive, the information provided on a product label should be clear and comprehensive. The product's type, identity, origin and properties should not be misleading. The issue of labelling was particularly significant in the case of imported goods, because terms used on labels that sound similar could have different meanings in a different country (Ustaborowicz-Jakimowicz, 1996, p. 242). The Decree of the Minister for Agriculture and Food Economy on labelling of food products, stimulants and permitted additives intended for trade turnover is the legal basis for regulations as regards labelling of foodstuffs (Rozporządzenie Ministra Rolnictwa..., 1994). Council Directive 90/496 EEC of 24 September 1990 on nutrition labelling for foodstuffs (Council Directive 90/496 EEC) and Council Resolution of 5 April 1993 on future action on the labelling of products in the interest of the consumer (Council Resolution 93/C 110/01) are also constituents of consumer legislation. The main aim of the resolutions was the introduction of consistent rules of publishing information 
about nutritional values on foodstuffs. It was intended to eliminate technical barriers to trade and improve the situation of consumers by enabling them to make informed choices (Eichler, 1996, p. 261). Information about price is another important issue. In the EU legislation, Council Directive 79/581/EEC of 19 June 1979 on consumer protection in the indication of the prices of foodstuffs (Council Directive 79/581) and Council Directive 88/314/EEC of 7 June 1988 on consumer protection in the indication of the prices of non-food products (Council Directive 88/314) regulate the right to information. The Act of 5 July 2001 on prices regulated the ways of informing about the quality and prices of goods and services.

The requirement to provide appropriate information on the terms and conditions of a contract, its subject and content of the object of performance, as well as possible effects, is a main quality of law of contracts and results from a contractual duty of loyalty (Grzybowski, 1974, p. 550). A specific form should be observed, for example, in writing. A consumer ought to be informed in written form about their special privileges (for instance the right of withdrawal) as in the case of off-premises contracts (Ustawa z dnia 2 marca 2000 r. o ochronie). The requirement of written form and providing specific and accurate information about contract terms is particularly respected by the European law concerning consumer loans (Council Directive 87/102).

It is worth mentioning the importance of the regulations included in the Act of 23 August 2007 on the prevention of unfair market practices (Ustawa z dnia 23 sierpnia 2007 r. o przeciwdziałaniu). The Act is the implementation of Directive 2005/29/EC of the European Parliament and of the Council of 11 May 2005 concerning unfair business-to-consumer commercial practices in the internal market (Directive 2005/29). Two new definitions appeared in the act, namely, the definition of a product and the offer of its purchase. The legislator pays attention to the fact that unfair market practices which mislead consumers can be based either on action or abandonment. Action does not always have to take the form of spreading untrue information, but even of giving true information if the way of providing it is misleading, thereby influencing the decision-making of an ordinary consumer, who otherwise would not have made that particular choice. Advertisements are a special source of information for consumers. When misleading, they can put consumers' interests at risk (Nowińska, Vall, 2000, p. 90).

At the time of Poland's accession to the European Union, Polish consumer policy had begun to follow the trends and accomplish the objec- 
tives of European consumer policy included in programs and strategies. The paramount goals in terms of consumer information and education were reflected in domestic consumer policy programs. The methods and scope of activities used to achieve those goals were the only distinction.

The current strategy of EU consumer policy is in the form of Regulation (EU) No 254/2014 of the European Parliament and of the Council of 26 February 2014 on the multiannual consumer programme for the years 2014-2020 (Regulation (EU) No 254/2014). According to Article 2 , the primary goal of the program is to guarantee a high level of consumer protection and strengthen consumer status. Consumer information and education, as well as the support of consumer organizations, are key elements. This is specifically connected with an increase in the level of education, information and awareness of consumers concerning their rights, the development of the database for consumer protection policy and, finally, providing support for consumer organizations taking into account the specific needs of consumers prone to different threats. Hence the adequate operations, which aim to ensure and improve the availability of the database, create smart regulations and detect dysfunctions of the market and changing consumer needs. They are also intended to determine the most problematic spheres for consumers, and include their interests in other EU policies. Furthermore, an increase in the transparency of consumer markets and information can be observed. Consumers ought to have access to comparable and reliable information, also in relation to crossborder transactions. Not only should they be able to compare prices, but also the quality and well-balanced nature of goods and services. In the years 2014-2020, the EU is focusing on an increase in the level of lifelong consumer education, especially of those individuals who are vulnerable to threats.

\section{Conclusions}

Education and information activities play an important role in consumer protection, especially as regards ignorance and lack of experience. Their main purpose is to enable consumers to adopt various attitudes in the process of conscious decision making when purchasing goods and services. Both information and education are essential elements of consumer policy in Poland. They consist of various methods of raising awareness, to prevent irrational or unnecessary purchases, and aim at the dissemination 
of consumer rights. A knowledgeable consumer, who is able to make use of their rights to seek redress, becomes a stakeholder for manufacturers and vendors. As a consequence, they are obliged to behave according to good commercial practices and business ethics. The process of adapting Poland to meet EU requirements resulted in the appearance of legal and institutional instruments which aim to protect consumer rights. However, the knowledge of rights and the awareness of possible actions are still at a low level among Polish consumers. They are not familiar with the rules of conditions of sale, do not read contracts, reluctantly make complaints about products which are unusable, presupposing that there is no prospect of success in a battle against strong manufacturers and that the judicial procedure is far too expensive, time-consuming and complicated. They do not know about the institutions and organizations acting on behalf of consumer protection and education, and they lack knowledge of the functioning of arbitration tribunals (Konsumentów portret..., 2007, p. 33).

The hypotheses formulated have been positively assessed. Education and information have been a paramount goal in government consumer policy programs. Any differences among particular programs have resulted from the measures taken in order to complete them. As far as contemporary EU consumer policy is concerned, it sets the minimum standards which a member state ought to meet. There is an opportunity for more effective consumer policy in the field of information and education, however, Poland achieves the minimum standards set.

Consumer education is a long-lasting and ongoing process of adaptation to the EU system, especially in a country with a rapidly developing market. One of the main barriers to consumer education and information is the lack of publication of a nationwide consumer affairs magazine. Hence, it is reasonable to spread knowledge about and popularize other sources of information and, in the case of the publications of consumer organizations, to create the conditions to publish them more widely (Ozimek, 1999, pp. 9-10). Moreover, the introduction of so-called 'consumer knowledge' into school curricula at all levels of education is another vital factor that leads to the development of consumer awareness, without which the work of consumer advocates, the Office of Competition and Consumer Protection and Trade Inspection will not yield the expected results (Niepokulczycka, 2003, p. 46).

Finally, all the measures concerning education and information of consumer protection entities are inherently limited, owing to their financial capacities. 


\section{References}

Consumer Policy Toolkit (2010), OECD, Paris.

Council Directive 79/112/EEC of 18 December 1978 on the approximation of the laws of the Member States relating to the labelling, presentation and advertising of foodstuffs for sale to the ultimate consumer, O. J. L 33/1, 08.02.1979.

Council Directive 87/102/EEC of 22 December 1986 for the approximation of the laws, regulations and administrative provisions of the Member States concerning consumer credit, O. J. L 42, 12.02.1987.

Council Directive 90/496 EEC of 24 September 1990 on nutrition labelling for foodstuffs, O. J. L 276/40, 06.10.1990.

Council Directive 79/581/EEC of 19 June 1979 on consumer protection In the indication of the process of foodstuffs, O. J. L 16/19, 26.06.1979.

Council Directive 88/314/EEC of 7 June 1988 on consumer protection in the indication of the process of non-food products, O. J. L 142/19, 09.06.1988.

Council Resolution 93/C 110/01 of 5 April 1993 on future action on the labelling of products In the interest of the consumer, O. J. C 110/1, 20.04.1993.

Departamenty, https://www.uokik.gov.pl/departamenty_uokik.php\#faq533, 23.07.2018.

Directive 2005/29/EC of the European Parliament and of the Council of 11 May 2005 concerning unfair business-to-consumer commercial practices in the internal market, O. J. L 149, 11.06.2005.

Dutkiewicz J. (1998), Stan świadomości konsumentów polskich na podstawie doświadczeń wynikających z poradnictwa prawnego Federacji Konsumentów, in: Socjoekonomiczna i prawna sytuacja konsumentów w Polsce w obliczu integracji z Unia Europejska, eds. K. Gutkowska, I. Ozimek, Wydawnictwo SGGW, Warszawa.

Eichler A. (1996), Komentarz do Dyrektywy 112/79/EEC, in: Harmonizacja polskiego prawa z regułami Unii Europejskiej. Ustawodawstwo konsumenckie w Unii Europejskiej, Stowarzyszenie Konsumentów Polskich Warszawa, vol. VI.

Grzybowski S. (1974), System prawa cywilnego. Część ogólna, Zakład Narodowy im. Ossolińskich Wrocław, vol. I.

Konsumentów portret wlasny - raport z badań (2007), Urząd Ochrony Konkurencji i Konsumentów, Warszawa.

Kirstein A. (2006), Rola rzecznika konsumentów w ksztaltowaniu świadomości konsumenckiej - refleksje praktyka, in: Edukacja konsumencka. Cele, instrumenty, dobre praktyki, ed. A. Lewicka-Strzałecka, Warszawa.

Łętowska E. (2004), Europejskie prawo umów konsumenckich, Wydawnictwo C.H. Beck, Warszawa.

Łuczak A., Odziemczyk T. (2006), Działania edukacyjne Stowarzyszenia Konsumentów Polskich, in: Edukacja konsumencka. Cele, instrumenty, dobre praktyki, ed. A. Lewicka-Strzałecka, Wydawnictwo Wyższej Szkoły Przedsiębiorczości i Zarządzania im. Leona Koźmińskiego, Warszawa. 
Nowińska E., Vall M. (2000), Wybór przepisów z zakresu prawa konsumenckiego, Wydawnictwo C.H. Beck, Warszawa.

Niepokulczycka M. (1993), Polityka konsumencka i ochrona interesów konsumentów, Federacja Konsumentów, Warszawa.

Niepokulczycka M. (2003), Rola organizacji pozarzadowych $w$ edukowaniu młodych konsumentów, in: Świadomość konsumencka i ochrona konsumentów doświadczenia francuskie, finskie a polskie perspektywy. Wystapienia zarejestrowane podczas konferencji międzynarodowej zorganizowanej w Warszawie w dniach 23 i 24 maja 2002 r., eds. P. Maghin, J. Małaszko, Urząd Ochrony Konkurencji i Konsumentów, Warszawa.

Niepokulczycki J., Zborowska W. (1993), Polityka konsumencka w Polsce jako niezbędny warunek dostosowań do Wspólnot Europejskich, Real Press, Warszawa.

Obwieszczenie Prezesa Rady Ministrów z dnia 19 maja 2018 r. w sprawie ogłoszenia jednolitego tekstu rozporządzenia Rady Ministrów w sprawie sposobu wspótdziałania organów Inspekcji Handlowej z powiatowym (miejskim) rzecznikiem konsumentów, organami administracji rządowej i samorządowej, organami kontroli oraz organizacjami pozarzadowymi reprezentujacymi interesy konsumentów, Dz. U. 2018, poz. 1072.

Ozimek I. (1999), Co polscy konsumenci wiedza o swoich prawach, "Biuletyn Urzędu Ochrony Konkurencji i Konsumentów", no. 23.

Polityka konsumencka na lata 2014-2018, Urząd Ochrony Konkurencji i Konsumentów, Warszawa 2014.

Regulation (EU) No 254/2014 of the European Parliament and of the Council of 26 February 2014 on a multiannual consumer programme for the years 2014-20 and repealing Decision No 1926/2006/EC, O.J. 84/42, 20.03.2014.

Resolution of the Council and the Ministers for Education, meeting within the Council, of 9 June 1986, on consumer education in primary and secondary schools, O. J. C 184, 23.07.1986.

Rokicka G. (2003), Robimy dużo, chcemy robić więcej, "Biuletyn Inspekcji Handlowej", no. 3 .

Rozporządzenie Ministra Rolnictwa i Gospodarki Żywnościowej z dnia 15 lipca 1994 r. w sprawie znakowania środków spożywczych, używek $i$ substancji dodatkowych dozwolonych, przeznaczonych do obrotu, Dz. U. 1994, Nr 86, poz. 402 z późn. zm.

Rozporządzenia Prezesa Rady Ministrów z dnia 5 lutego 1997 r. w sprawie nadania statutu Urzędowi Ochrony Konkurencji i Konsumentów, Dz. U. 1997, Nr 12, poz. 66.

Rozporządzenie Rady Ministrów dnia 19 października 1999 roku w sprawie zasad wspótpracy organów Inspekcji Handlowej z powiatowym (miejskim) rzecznikiem konsumentów, a także z innymi organami administracji publicznej $i$ instytucjami kontrolnymi, w tym organizacjami pozarzadowymi, działajacymi w zakresie ochrony interesów konsumentów, Dz. U. 1999, Nr 87, poz. 969. 
Rozporządzenie Ministra Edukacji Narodowej z dnia 14 lutego 2017 r. w sprawie podstawy programowej wychowania przedszkolnego oraz podstawy programowej kształcenia ogólnego dla szkoły podstawowej, w tym dla uczniów z niepetnosprawnościa intelektualna w stopniu umiarkowanym lub znacznym, kształcenia ogólnego dla branżowej szkoły I stopnia, kształcenia ogólnego dla szkoły specjalnej przysposabiającej do pracy oraz kształcenia ogólnego dla szkoły policealnej, Dz. U. 2017, poz. 356.

Statut Federacji Konsumentów, http://www.federacja-konsumentow.org.pl/, 23.07.2018.

Statut Stowarzyszenia Konsumentów Polskich, http://www.skp.pl/index.php/statutskp, 21.07.2018.

Streżyńska A. (2000), Ochrona konsumentów w Unii Europejskiej i Polsce, Elipsa, Warszawa.

Treaty on European Union, O. J. C 191, 29.07.1992.

Treaty of Amsterdam amending the Treaty on European Union, the Treaties establishing the European Communities and certain related acts, O. J. C 340, 10.11.1997.

Układ Europejski ustanawiający stowarzyszenie między Rzeczpospolita Polska, z jednej strony, a Wspólnotami Europejskimi i ich państwami, z drugiej strony, sporządzony w Brukseli dnia 16 grudnia 1991 r., Dz. U. 1994, Nr 11, poz. 38.

Ustawa z dnia 23 kwietnia 1964 r. - Kodeks cywilny, Dz. U. 1964, Nr 16, poz. 93 z późn. zm.

Ustawa z dnia 7 kwietnia 1989 r. - Prawo o stowarzyszeniach, Dz. U. 2001, Nr 79, poz. 855 z późn. zm.

Ustawa z dnia 7 września 1991 r. o systemie oświaty, Dz. U. 1991, Nr 95, poz. 425 z późn. zm.

Ustawa z dnia 7 października 1999 r. o języku polskim, Dz. U. 1999, Nr 90, poz. 999 $\mathrm{z}$ późn. $\mathrm{zm}$.

Ustawa z dnia z dnia 15 grudnia 2000 r. o Inspekcji Handlowej, Dz. U. 2001, Nr 4, poz. $25 \mathrm{z}$ późn. zm.

Ustawa z dnia 5 lipca 2001 r. o cenach, Dz. U. 2001, Nr 97, poz. 1050 z późn. zm.

Ustawa z dnia 2 marca 2000 r. o ochronie niektórych praw konsumentów oraz o odpowiedzialności za szkodę wyrządzona przez produkt niebezpieczny, Dz. U. 2000, Nr 22, poz. 271 z późn. zm.

Ustawa z dnia 23 sierpnia 2007 r. o przeciwdziałaniu nieuczciwym praktykom rynkowym, Dz. U. Nr 171, poz. 1206.

Ustawa z dnia 16 lutego 2007 r. o ochronie konkurencji i konsumentów, Dz. U. 2007, Nr 331, poz. 50 z późn. zm.

Ustaborowicz-Jakimowicz L. Komentarz do Dyrektywy 112/79/EEC, in: Harmonizacja polskiego prawa z regułami Unii Europejskiej. Ustawodawstwo konsumenckie w Unii Europejskiej, Stowarzyszenie Konsumentów Polskich, Warszawa, vol. VI. 
Wymysłowski S. (2006), Poradnictwo prawne jako forma edukacji konsumenckiej Federacji Konsumentów, Polskich, in: Edukacja konsumencka. Cele, instrumenty, dobre praktyki, ed. A. Lewicka-Strzałecka, Wydawnictwo Wyższej Szkoły Przedsiębiorczości i Zarządzania im. Leona Koźmińskiego, Warszawa.

10 lat (2000), Urząd Ochrony Konkurencji i Konsumentów, Warszawa.

\title{
Edukacja i informacja w polityce konsumenckiej w Rzeczypospolitej Polskiej
}

\begin{abstract}
Streszczenie
Artykuł oparty został na analizie aktów prawa krajowego i unijnego, dokumentów oraz literatury przedmiotu i ma na celu przedstawienie edukacji i informacji w polityce konsumenckiej w Polsce. Ochrona praw konsumentów w aspekcie informacyjnoedukacyjnym ukazana została jako nadrzędny cel strategii polityki konsumenckiej Unii Europejskiej oraz rządowych programów polityki konsumenckiej w Polsce. Analizie poddano wybrane aspekty polityki edukacyjnej i informacyjnej rządu, zawarte w „Strategii polityki konsumenckiej na lata 2014-2018”. W kontekście instytucjonalnym omówiono kompetencje poszczególnych podmiotów ochrony praw konsumenta w zakresie edukacji i informacji w Polsce. Wskazano ponadto na tożsamość konsumenckiej informacyjno-edukacyjnej polityki krajowej z unijną.

Słowa kluczowe: Federacja Konsumentów, konsument, Inspekcja Handlowa, polityka konsumencka, prawa konsumenta, Stowarzyszenie Konsumentów Polskich, Urząd Ochrony Konkurencji i Konsumentów
\end{abstract}


